\title{
Introduction: The Magic Mix
}

\begin{abstract}
Ali Shehzad Zaidi ${ }^{1}$
[Article copies available for a fee from The Transformative Studies Institute.E-mail address: journal@transformativestudies.org Website: http://www.transformativestudies.org (C2021 by The Transformative Studies Institute. All rights reserved.]
\end{abstract}

For several years, I knew Mohammad Zaman only as the courteous and unassuming physician whose clinic I would visit for allergy shots. Steady exposure to a concoction of mold, dust, pollen, and other allergens gradually opened my constricted bronchial tubes, providing relief during the allergy season. Although I ceased to visit the clinic, I continued to cross paths with Zaman on social occasions. Recently he shared with me the poems that make up this debut collection.

A poet, like an allergist, practices alchemy, only with different ingredients, mixing wonder, love, mystery, and revery to open portals to unsuspected dimensions of existence. Such is the case in "I Rise To Undo My Death" whose cosmic perspective and intimacy define a father as an address and a compass in a universe that is at once dark and luminous:

When the heart is broken and spirit down

when the sun is setting and welkin painted

I sit on the river bank and drink

my glass of wine, my eyes closed,

I set my spirit free.

I am the son of my father.

I am the light of a billion stars.

Fireflies light the garden of night.

\footnotetext{
${ }^{1}$ Ali Shehzad Zaidi, Ph.D., is the editor of Theory in Action. He teaches Spanish and French language at SUNY Canton and was awarded the SUNY Chancellor's Award for Scholarship and Creative Activities in 2020. Address correspondence to: Ali Shehzad Zaidi, e-mail: azaidi@transformativestudies.org.
} 